\title{
Professor Johnson's Heresy Hunt
}

\section{Author(s): J. Morris Jones}

Source: The Celtic Review, Vol. 1, No. 3 (Jan., 1905), pp. 276-281

Stable URL: http://www.jstor.org/stable/30069825

Accessed: 27-06-2016 09:15 UTC

Your use of the JSTOR archive indicates your acceptance of the Terms \& Conditions of Use, available at

http://about.jstor.org/terms

JSTOR is a not-for-profit service that helps scholars, researchers, and students discover, use, and build upon a wide range of content in a trusted digital archive. We use information technology and tools to increase productivity and facilitate new forms of scholarship. For more information about JSTOR, please contact support@jstor.org. 
of clan history since Logan wrote the text for the original edition, and consequently the letterpress has been subjected to correction, and further details are added in regard to the music of the various clans. Information as to the regiments associated with the clans is also added as a new feature. The letterpress has been intrusted to the able hands of Mr. Henry Whyte ('Fionn'). The completed work will contain eighty plates, and the four in the present number are handsomely reproduced. Certainly the difference in price between this and the original edition, which was published at $£ 30$, is striking, and many persons will be glad to avail themselves of the opportunity of having such a beautiful and valuable work, whether they purchase the parts, or wait for the completed and bound book, of which there is also to be an edition de luxe.

The Irish and Highland Harps. Robert Bruce Armstrong.-We much regret a mistake in the review of this book, the price being given as 4 guineas instead of 3 guineas.

All lovers of Celtic music must feel how much Scotland has lost by the death of Mr. John Glen, whose name is so intimately and so honourably connected with all that is best in the domain of Scottish and Highland music, and whose own musical works are treasure houses of valuable information, accumulated by much painstaking study and search. It is greatly to be desired that the unique collections of ancient musical instruments, some of them obsolete, and of books on music, numbering over 300 volumes, made by him, might be procured for the Scottish nation and deposited in some fitting place where they may be of benefit and interest to those who desire to consult them.

\section{NOTES}

\section{Professor Johnson's Heresy Hunt}

Professor H. H. Johnson's attack upon me in the October number of the Celtic Review makes it necessary that I should say a few words in reply. I say his attack upon me, for that is, in the main, what it is. It is true that Professor Rhŷs and Sir William Preece are named; but Sir William Preece's paper is not philological, and Professor Johnson is unable to adduce anything against Professor Rhŷs except a derivation of Brython, which may be right or may be wrong, but has nothing in the world to do with 'the heresy of connecting Welsh and Semitic.' But my paper on 'Pre-Aryan Syntax,' published as an appendix to The Welsh People, is referred to three times in his opening paragraph.

He talks of it as 'this recrudescence of eighteenth-century philology.' $\mathrm{He}$ accuses me of deriving Welsh words from Arabic; he mentions some 
words which are similar in form in the two languages. He then says, 'Some of these are in the appendix already twice mentioned.' There is nothing at all remotely resembling these equations in my paper. Again, when he says, further down, 'If Professor Morris Jones compares pronominal suffix ha and $h i$ in Arabic and Welsh,'-is not this meant to suggest that I have made such a comparison? Having led his readers to believe that I am guilty of propounding these absurd derivations of Welsh from Arabic, he devotes a great part of his article to making fun of them-a very easy thing to do. $\mathrm{He}$ quotes every foolish etymology he can think of. 'What I wish to be understood by the above,' he says, 'is that we should not be led astray by unscientific etymologies of Welsh.'

Now I hope it is unnecessary for me to say that I have never, in the paper in The Welsh People or anywhere else, suggested the derivation of any Welsh word from Arabic or Egyptian or Berber or any other Semitic or Hamitic language. The title of my paper is 'Pre-Aryan Syntax in Insular Celtic'; it deals with syntax only ; indeed, it is expressly stated in it that ' I have confined myself strictly to syntax, and have not ventured to suggest any phonetic equation' (p. 638). What is to be thought of a man who in the face of this pretends that the paper mainly consists of absurd etymologies? But Professor Johnson is not content with attributing absurd etymologies to me; he even pretends to trace this puerile philology to its source in the seventeenth-century derivation of Welsh from Hebrew. 'They ransack the old seventeenth and eighteenth century superannuated books, and produce an appendix or paper.' Thus he not only invents the heresy, but invents a history of it.

I do not mean to suggest that it is 'deliberate misrepresentation,' to use an expression quoted in Mr. Johnson's article. Heresy hunters are generally persons who cannot distinguish between error and advance in doctrine. Professor Johnson knows nothing about Celtic philology, or Aryan philology for the matter of that. He knows nothing of the preAryan problem; he has evidently read nothing about the ethnology of the question except a single article by Huxley, which he quotes unwittingly against himself. He has apparently never seen The $W$ elsh People; he speaks of it as the work of Mr. Brynmor-Jones, without mentioning Professor Rhŷs, whose name appears first on the title-page; all he knows of my paper apparently is a reference or two to it at the Celtic Congress, the rest of his description he supplied from his own imagination. He may be acquitted of wilful misrepresentation; but he cannot be acquitted of making reckless statements without troubling to verify his facts.

Perhaps I had better state in as few words as possible what my paper, which is the subject of his attack, does contain. Briefly, then, the Celticspeaking population of these islands belongs to the primitive race, to a race which inhabited Western Europe before the arrival of Aryan speakers. The Celtic languages, being Aryan, have therefore been imposed by their original speakers upon the bulk of their present speakers, who in the words of Huxley, 
quoted by Mr. Johnson, 'are merely, so to speak, secondary Celts.' The primitive race is believed to be of the same stock as the ancient Iberians, an identification which is as old as Tacitus and still holds the field. The question is whether the Celtic languages acquired by this race exhibit any traces of the non-Aryan language originally spoken by the race. Professor Rhy $\hat{s}$ answered this question in the affirmative more than twenty years ago. 'Anthropologists,' said Dr. Beddoe in 1885,1 'have long been awaiting the appearance of some philologist fully qualified to determine the important problem whether there be really an Euskarian or Iberian element in the Kymric languages. ... Professor Rhŷs has answered our call with the assurance that the element which physical phenomena has led us to look for does really exist.'

Where in the Celtic languages is this element to be looked for? Not in the vocabulary, as is shown by historical examples of one language being supplanted by another, e.g. the minuteness of the Gaulish element in the French vocabulary. There are many Welsh and Irish words which cannot be explained from Aryan roots, and some of them may possibly be derived from a pre-Celtic tongue, but I have never pretended that I have discovered the origin of any one of them. With regard to syntax, however, the case is different; the structure of the old language may very well, and frequently does, persist in the new. An extreme example is Pigeon English; but the phenomenon of such a mixture is common enough in different parts of the world. The peculiar constructions of Welsh and Irish, which have always puzzled our grammarians, are therefore exactly the non-Aryan element which we should expect to find. Some years ago philologists denied the possibility of mixture in language, in the very teeth of the fact that mixed languages do actually exist. Aryan was held to be a simple homogeneous whole, entirely uninfluenced by the dialects supplanted by it in Europe and Asia. Professor Johnson still preaches this antiquated superstition: 'Aryan is Aryan,' he says, 'and must not be mixed, however slightly, except as regards loan-words, with other great divisions of human speech.' This doctrine I was perfectly well acquainted with in my undergraduate days; and I answered Mr. Johnson by anticipation when I quoted at the head of my paper, from O. Schrader's Prehistoric Antiquities of the Aryan Peoples, English translation, p. 113, "The notion of a "mixed language" must have much more weight assigned to it than has heretofore been allowed.' I now quote a more recent pronouncement on the same subject, it is from Sweet's most excellent little manual on The History of Language, 1900 , p. 85 , 'The comparative philologist must realise that any one of the ancient languages he has to deal with-however classical and elaborately literary it may be in its extant form-may have been originally a "substitution-dialect" like Pigeon English.' Aryan is Aryan, no doubt, so is gold gold; but all that we call Aryan is no more unalloyed Aryan than all that goes by the name of gold is pure gold.

\section{The Races of Britain, p. 26.}


The next question is what this language was, which left its influence on the Celtic by which it was supplanted. Dr. Beddoe, in the extract quoted above, and Huxley, in the passage quoted by Professor Johnson, take for granted that it was Euskarian or Basque, that being the only surviving nonAryan language in Western Europe. Professor Johnson does not consider this suggestion absurd when it comes from Huxley; and, forgetting his maxim that Aryan is Aryan, admits the possibility 'that a connection exists between Basque and Celtic.' He investigates the evidence for it, and finds it not proven. If he had read my paper he would have seen that I had come to the same conclusion. As to the ethnology of the Basques, absolutely all Professor Johnson knows about the matter is that Van Eys implied that they were fair, and that Huxley calls them 'melanochroi.' For his information I may say that Ripley, in the Races of Europe, has twenty-four pages on the subject, with two pages of portrait plates. The Basques are a mixed race, and their language, which in structure is perhaps to be classed with the agglutinative Finno-Ugric tongues, is probably that of the broad-headed northern Basques, who have Lappish affinities, and not of the long-headed Iberians of the south.

The Iberians belong to the Mediterranean race. This race inhabits Southern Europe and North Africa. ${ }^{1}$ To this race, according to Sergi, we owe the two classic civilisations, Greek and Latin, which the invading Aryan savages only retarded. The substantial unity of the European and African branches of the race is, as Ripley says (p. 130), 'recognised by all authorities.' Its representatives in Africa are the Berbers and the ancient Egyptians. Now what does Professor Johnson know about the ethnology of the Mediterranean race? Absolutely nothing whatever. He has read no book which touches the subject, except an ante-diluvian work on Adam, and a natural history published in 1769 , from which latter he learns that the Berbers' are negroes! He then asks me, 'Why conceive the graceless theory' of our connection with them? It is not my theory, but that of modern anthropologists ; it is not graceless to any one who knows the difference between black and white.

The source of my linguistic theory is this theory of the anthropologists, as I have stated in my paper, and not the inanities of seventeenth-century etymologists, as Professor Johnson asserts. It is reasonable to suppose that the various divisions of the Mediterranean race originally spoke allied languages. Presumably, therefore, the pre-Celtic speech of these islands belonged to this linguistic family, of which, Basque having been ruled out, the only known representatives are the so-called Hamitic languages of North Africa, including Old Egyptian and the Berber dialects. The peculiarities of neo-Celtic syntax, then, are derived, not indeed directly from these, but from a lost language allied to these. So I argued in 1891. I confess I did

1 See Ripley's Races of Europe, pp. 128-130, 246-280.

2 Confusing them with the Barabra (sing. Berberi), a mixture of Arabs and Ethiopians. 
not expect to discover much similarity between the syntax of our pre-Aryan tongue as it persists in Celtic and that of its cognate languages in Africa. I hardly thought the chance of finding Welsh idioms in Renouf's Egyptian Grammar worth the seven shillings and sixpence asked for the book. I bought it, however, and found in it what I had not dared to expect. I found that the ancient Egyptian formed his sentences in exactly the same way as the modern Welshman forms his; I found nearly all the constructions which I had noted as peculiar in Welsh described in this book, some of them in almost the very words which I myself had used in describing the Welsh constructions. I made no haste to publish. My notes first appeared in 1900, in The Welsh People, pp. 617-641. In this paper I have compared Celtic with Hamitic syntax, not with Arabic at all; some of the constructions occur in Arabic, owing to a remote connection between Hamitic and Semitic ; but, as I have distinctly stated, Celtic syntax agrees with Hamitic; 'it agrees with Egyptian where both differ from Arabised Berber.'

I do not intend here to repeat these comparisons, for which I must refer the reader to the pages of The Welsh People. I ought, however, to mention one of them, which Professor Johnson tries to explain away. In the neoCeltic tongues the verb comes first in every simple sentence without exception; if a noun comes first the sentence is a mixed one. This is true of Hamitic also. ${ }^{1}$ But in Aryan the verb naturally comes last. Professor Johnson's answer is that it may come first in Aryan; 'Spake full well . . . a bard.' He does not see that there is all the difference in the world between a language in which it must be put first, and one in which it may, in artificial diction, be put first. He might as well argue that there is no difference between a man and a dog because the dog may stand on its hind legs.

I need say no more now about my theory of the connection of neo-Celtic and Hamitic. Professor Johnson says, 'Brugmann is apparently scouted in Gallant Little Wales.' If he will read my article on Cymraeg in the second edition of the Gwyddoniadur, written in the days of my youth, he will find that I knew my Brugmann then. There is nothing inconsistent with Brugmann in my theory, which has, in fact, had the assent of a translator of Brugmann. I do not wish to mention any names in connection with it, being content that it should be taken on its own merits. I may mention here, since Professor Johnson speaks of Professor Anwyl and Professor Kuno Meyer as sharing his views, that both have dissociated themselves from him, the former publicly in The Welsh Leader, the latter in a letter to me.

We have seen how much Professor Johnson knows about ethnology; what does he know about philology that he should deliver us a lecture on how 'the ideal Celtic etymologist' should proceed? The philo-

1 The Semitic construction is different when the noun comes first. I regret I have no space at my disposal to make this clear. Of course I never compared Welsh with Arabic, as Mr. Johnson suggests. 
logical platitudes which he utters with such an oracular air have not even been digested by him. For example, on page 170 he says, "The strange impersonal $r$ common to Latin and Celtic seems almost to justify the tentative expression "Italo-Celtic quasi-unity." The $r$ is a small matter to base the theory on, but of the close relation between Italic and Celtic there can be no doubt. Now on the very next page Mr. Johnson writes, 'The relation between Celtic and Teutonic is, approximately, that between Celtic and Latin, but with a preponderance on the side of Teutonic.' If this means anything, it means that Celtic is more closely related to Teutonic than to Latin; he has forgotten all about the Italo-Celtic unity of the previous page. Again, the man who accuses me of propounding foolish etymologies, which I have never done, does this very thing himself in this article. He gives a list of Italian words derived from Celtic. Here is one example: Italian cipolla, from the original of Welsh sibol. He does not know that Welsh sibol (or sibols, sing. sibolsen) is a late borrowing, hardly naturalised, of the English cibbols. Note further how he betrays his ignorance of phonology: he imagines that Celtic $c$ can become $s$ in Welsh! Once more, he compares Basque gizon-a, 'the man,' with Welsh 'plent-yn (from plant, with modified vowel ?).' Here two things are seen : (1) he does not know the difference between agglutination and inflexion; (2) the '?' shows that he does not know the elementary phonetic rule in Welsh, which I should be vexed with a junior student in his first term for not knowing, that $y$ in the ultima always modifies $a$ in the penult; e.g. adar, aderyn; gwlad, gwledydd; asgwrn, esgyrn; pebyll from papilio.

Perhaps his article contains nothing more amazing than the first sentence in his last paragraph: 'But I must draw to a close, begging to be kindly criticised, even as I have tried kindly to criticise my countrymen.' I may be ungrateful, but his article seems to me to be about as kind as it is critical.

Bangor, Dec. 1904.

J. MORRIS Jones.

\section{Celt and Semite}

The article by Professor Johnson in the Celtic Review of October is interesting, and it is written in genuine good-humoured style. This is rather unique when one takes into account that it is the case of a Celt demolishing heresy. He scarcely needed to put in a plea for kindness at the hands of any possible critic. Indeed, some of us are disposed to think that his article is meant to be taken less as a serious argument than as a bit of banter. It discloses a situation which lends itself beautifully to the mood of the humorist. We get a peep at Professor Kuno Meyer shooting his best arrow tipped with choice sarcasm. Professor Morris Jones, shy as a country lass, modestly bobs behind Principal Rhŷs. Professor Anwyl is clad in sack-cloth and covered with confusion because of the disgraceful behaviour of Welsh Philologues. And we have Professor Johnson himself 